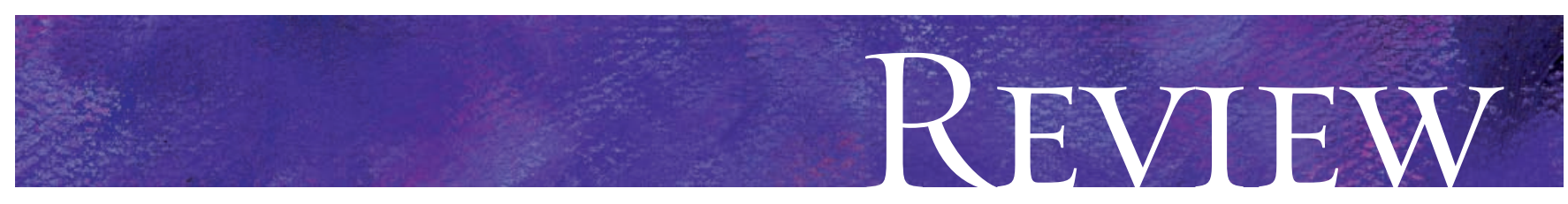

\title{
Neuropathic pain: a practical guide for the clinician
}

\author{
Ian Gilron, C. Peter N. Watson, Catherine M. Cahill, Dwight E. Moulin
}

\section{ABSTRACT}

Neuropathic pain, caused by various central and peripheral nerve disorders, is especially problematic because of its severity, chronicity and resistance to simple analgesics. The condition affects $2 \%-3 \%$ of the population, is costly to the health care system and is personally devastating to the people who experience it. The diagnosis of neuropathic pain is based primarily on history (e.g., underlying disorder and distinct pain qualities) and the findings on physical examination (e.g., pattern of sensory disturbance); however, several tests may sometimes be helpful. Important pathophysiologic mechanisms include sodium- and calcium-channel upregulation, spinal hyperexcitability, descending facilitation and aberrant sympathetic-somatic nervous system interactions. Treatments are generally palliative and include conservative nonpharmacologic therapies, drugs and more invasive interventions (e.g., spinal cord stimulation). Individualizing treatment requires consideration of the functional impact of the neuropathic pain (e.g., depression, disability) as well as ongoing evaluation, patient education, reassurance and specialty referral. We propose a primary care algorithm for treatments with the most favourable risk-benefit profile, including topical lidocaine, gabapentin, pregabalin, tricyclic antidepressants, mixed serotonin-norepinephrine reuptake inhibitors, tramadol and opioids. The field of neuropathic pain research and treatment is in the early stages of development, with many unmet goals. In coming years, several advances are expected in the basic and clinical sciences of neuropathic pain, which will provide new and improved therapies for patients who continue to experience this disabling condition.

CMAJ 2006;175(3):265-75

$\mathrm{N}$ europathic pain, caused by a lesion of the nervous system, ${ }^{1,2}$ is especially problematic because (a) it is often experienced in parts of the body that otherwise appear normal, (b) it is generally chronic, severe ${ }^{3}$ and resistant to over-the-counter analgesics, ${ }^{4}$ and (c) it is further aggravated by allodynia (touch-evoked pain). ${ }^{5}$ It may result from various causes that affect the brain, spinal cord and peripheral nerves, including cervical or lumbar radiculopathy, diabetic neuropathy, cancer-related neuropathic pain, postherpetic neuralgia, HIV-related neuropathy, spinal cord injury, trigeminal neuralgia and complex regional pain syndrome type II, among others. ${ }^{6}$ Complex regional pain syn- drome type I is not considered a cause, because there is no definable nerve lesion. The epidemiology of neuropathic pain has not been adequately studied, partly because of the diversity of the associated conditions. Current pooled estimates suggest that neuropathic pain may affect as much as $3 \%$ of the population..$^{7-13}$

The personal impact of neuropathic pain is most vividly appreciated by people who experience this devastating condition. Those affected have described their pain using the McGill Pain Questionnaire ${ }^{14}$ with descriptors such as "punishing-cruel" and "tiring-exhausting." ${ }^{15,16}$ Ample evidence indicates that neuropathic pain impairs patients' mood, quality of life, activities of daily living and performance at work..$^{9,17,18}$ People with the condition have been found to generate 3 -fold higher health care costs compared with matched controls. ${ }^{19}$ In the United States, health care, disability and related costs associated with chronic pain have been estimated at $\$ 150$ billion annually, ${ }^{20}$ of which almost $\$ 40$ billion is attributable to neuropathic pain.

\section{Clinical presentation and patient evaluation}

The blockade of nerve conduction in neuropathic conditions causes nerve dysfunction, which can result in numbness, weakness and loss of deep tendon reflexes in the affected nerve area. Neuropathic conditions also cause aberrant symptoms of spontaneous and stimulus-evoked pain. Spontaneous pain (continuous or intermittent) is commonly described as burning, shooting or shock-like. ${ }^{15,21-26}$ Stimulusevoked pain includes allodynia (pain evoked by a nonpainful touch) and hyperalgesia (increased pain evoked by a painful stimulus). Allodynia can be caused by the lightest stimulation, such as skin contact with clothing or a light breeze. These sensory abnormalities may extend beyond nerve distributions (Fig. I), which may lead to the inappropriate diagnosis of a functional or psychosomatic disorder. The diagnosis of neuropathic pain is based primarily on history and findings on physical examination. ${ }^{27}$

Assessment of the patient with suspected neuropathic pain should focus on ruling out treatable conditions (e.g., spinal cord compression, neoplasm), confirming the diagnosis of neuropathic pain and identifying clinical features (e.g., insomnia, autonomic neuropathy) that might help individualize treatment. Box I lists principal details of the clinical evaluation, including history, physical examination and special tests. 


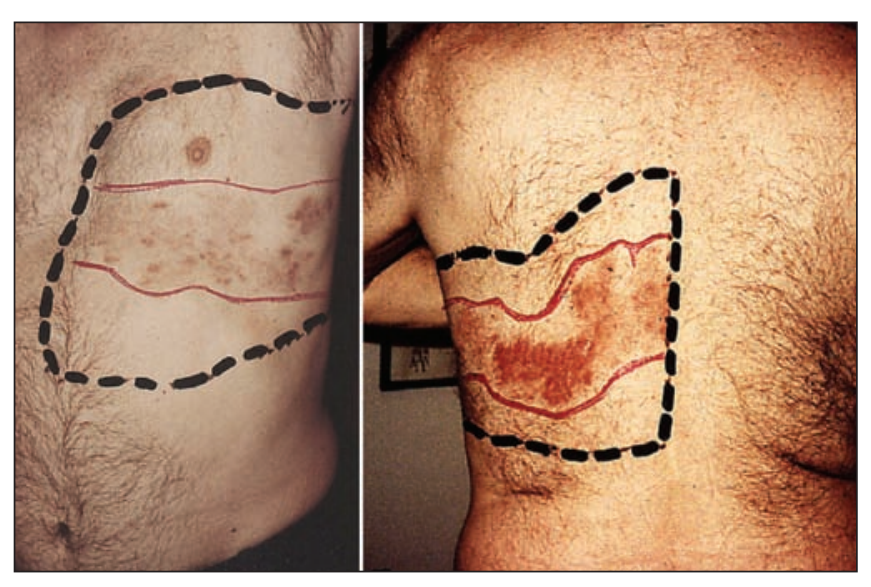

Fig. 1: Man with postherpetic neuralgia in the left fifth and sixth thoracic dermatomes. Red lines delineate area of sensory loss, and black dashed lines delineate area of allodynia (touchevoked pain). Extension of allodynia above and below the originally affected dermatomes is a feature of central sensitization.

\section{Pathophysiology and molecular mechanisms of neuropathic pain}

Table I highlights the clinical and pathophysiologic features of common neuropathic pain syndromes that are caused by nerve injury or dysfunction. Knowledge of the cellular and molecular mechanisms of neuropathic pain has advanced with the development of various experimental models of nerve injury. ${ }^{50}$ Both peripheral and central mechanisms (Fig. 2) have been proposed as being relevant to the pathogenesis of neuropathic pain..$^{51}$

\section{Peripheral mechanisms}

Regeneration after nerve injury results in the formation of neuromas ${ }^{52,53}$ and sprouting of new nerve projections among uninjured neighbouring neurons. ${ }^{54}$ Collateral sprouting then leads to altered sensory properties that may be realized as expanded receptive fields. Uncontrolled neuronal firing after experimental nerve injury is largely attributed to increased expression of sodium channels. This mechanism is supported by several lines of evidence, including blockade of neuropathic pain with sodium-channel-blocking local anesthetics. ${ }^{55}$ Demyelination of diseased nerves may be another cause of increased neuronal excitability. ${ }^{56}$

In addition to sodium channels, expression of voltagegated calcium channels is also increased following nerve injury.$^{57}$ Calcium entry through voltage-gated calcium channels is necessary for the release of substance $\mathrm{P}^{58}$ as well as glutamate from injured peripheral nerves. Within the dorsal root ganglion, increased expression of the $\alpha$-2-delta subunit of voltage-gated calcium channels correlates with onset and duration of allodynia. ${ }^{59}$ Clinical support of the role of this protein in neuropathic pain arises from the analgesic efficacy of $\alpha$-2-delta voltage-gated calcium-channel antagonists, gabapentin and pregabalin. ${ }^{60,61}$

\section{Central mechanisms}

Sustained painful stimuli result in spinal sensitization, ${ }^{62}$ which is defined as heightened sensitivity of spinal neurons, reduced activation thresholds and enhanced responsiveness to synaptic inputs (i.e., more likely to transmit pain to the brain). ${ }^{63}$ This can manifest in expansion of the affected area, increased response to painful inputs and transmission of pain following nonpainful stimuli. ${ }^{64}$ Central sensitization is largely mediated by the $N$-methyl-Daspartate (NMDA) receptor. Although experimental NMDAreceptor blockade clearly suppresses central sensitization, ${ }^{65}$ analgesic efficacy of NMDA antagonists has been disappointing, likely because of the narrow therapeutic window of available agents. ${ }^{61}$

Activation of descending pathways (the periaqueductal greyrostral ventromedial medulla ${ }^{66}$ has been shown to reduce pain transmission in animals ${ }^{67}$ and humans ${ }^{68}$ and is thought to contribute to the analgesic effect of opioids and antidepressants. Paradoxically, this system can also facilitate pain transmis$\operatorname{sion}^{69}$ and may contribute to some chronic pain states. ${ }^{70}$

\section{Sympathetically maintained pain}

The importance of the sympathetic nervous system in neuropathic pain has been demonstrated by analgesia following sympathectomy in animals ${ }^{71}$ and humans, ${ }^{72}$ and by pain exacerbation through activation of the sympathetic nervous system. ${ }^{73}$ Sympathetically maintained pain may be explained by sprouting of sympathetic neurons into dorsal root ganglia of injured sensory neurons ${ }^{74}$ and postinjury sprouting of sympathetic fibres into the dermis. ${ }^{75}$

\section{Current management}

\section{Nonpharmacologic}

Although many patients with neuropathic pain pursue complementary and alternative treatments, rigorous evidence supporting efficacy of nondrug therapy is limited. Some reports suggest benefits of conservative interventions such as exercise, ${ }^{76}$ transcutaneous electrical nerve stimulation, ${ }^{77}$ percutaneous electrical nerve stimulation, ${ }^{78}$ graded motor imagery $^{79}$ and cognitive behavioural therapy or supportive psychotherapy. ${ }^{80}$

\section{Pharmacologic}

One approach to estimate treatment efficacy using randomized controlled trial (RCT) data is based on the numberneeded-to-treat (NNT) to obtain at least 50\% pain relief in one patient. The NNT concept is hampered by methodologic variability across different RCTs, the short-term nature of most RCTs and the lack of consideration for other important outcomes (e.g., disability, quality of life). Also, most RCTs have involved patients with diabetic peripheral neuropathy and postherpetic neuralgia, and the results do not necessarily apply to all neuropathic pain conditions. 


\section{Antidepressants}

Tricyclic antidepressants have repeatedly been shown to reduce neuropathic pain. ${ }^{81}$ Analgesic actions may be attributable to noradrenaline and serotonin reuptake blockade (presumably enhancing descending inhibition), NMDA-receptor antagonism and sodium-channel blockade. ${ }^{82}$ The NNT is about 3 both for balanced noradrenaline and serotonin reuptake inhibitors (e.g., amitriptyline) and predominantly noradrenaline reuptake inhibitors (e.g., nortriptyline) ${ }^{61}$

Selective serotonin reuptake inhibitors $(\mathrm{NNT}=6.7)^{83}$ and mixed serotonin-noradrenaline reuptake inhibitors (venlafaxine and duloxetine $\left.{ }^{84} \mathrm{NNT}=4 \cdot \mathrm{I}-5 \cdot 5\right)^{61}$ do not appear to be as effective as tricyclic antidepressants.

\section{Anticonvulsants}

Based on methodologically flawed trials, carbamazepine and phenytoin have NNTs of 2.I-2.3 for diabetic peripheral neuropathy ${ }^{61}$ Both have significant adverse effects, making them generally poor candidates for first-line therapy. Carbamazepine, however, is still considered first-line therapy for trigeminal neuralgia, a unique neuropathic pain condition $(\mathrm{NNT}=\mathrm{I} .7) .{ }^{61}$ Oxcarbazepine, a newer anticonvulsant structurally related to carbamazepine, may also be useful; however, only one RCT (in diabetic peripheral neuropathy) has been published. ${ }^{85}$

Gabapentin, an $\alpha$-2-delta subunit voltage-gated calciumchannel antagonist, ${ }^{86}$ has repeatedly demonstrated analgesic

\section{Box 1: Clinical evaluation of patients with suspected neuropathic pain}

\section{History}

Pain intensity

- 0 -10 rating scale $(0=$ no pain, $10=$ worst pain imaginable)

- Rate pain at initial presentation and at subsequent visits to track treatment response

Sensory descriptors ${ }^{15,21-26}$

- Pain qualities: hot, burning, sharp, stabbing, cold, allodynia (pain brought on by light touch, clothing or bed sheets)

- Common nonpainful sensations: tingling, prickling, itching, numbness and "pins and needles"

Temporal variation

- Neuropathic pain often gets worse towards the end of the day ${ }^{28}$

- Neoplastic process should be suspected if pain has been progressively increasing over recent months

Functional impact

- Effect of pain on sleep, ${ }^{29}$ ambulation, self-care, activities of daily living, work, social or sexual function, mood $^{30}$ and suicidal ideation ${ }^{31}$

Attempted treatments

- Neuropathic pain is generally resistant to acetaminophen and NSAIDs

- Determine and document adequacy of dose titration for titratable drugs (e.g., dose reached and duration of treatment, drug treatment stopped owing to adverse effects or lack of efficacy) ${ }^{32}$

Alcohol or substance abuse

- Addiction history will affect decision to prescribe opioids or cannabinoids

- Consider earlier involvement with a psychologist or psychiatrist $^{33}$

- Consider safety of sedative analgesics with alcohol or other sedatives

Physical examination

Gross motor examination

- Motor weakness may occur around the involved nerves

- Attempt to differentiate between true weakness and antalgic weakness

Deep tendon reflexes

- May be diminished or absent around the involved nerves

\section{Sensory examination}

- Light touch, pin prick, vibration sense and proprioception may be diminished or absent in the involved nerve territory

- Sensory disturbance may aberrantly extend beyond a discrete nerve territory

- Dynamic allodynia (pain due to cotton wool lightly moving across the skin)

- Thermal allodynia (burning sensation in response to ice cube on skin)

- Pinprick hyperalgesia (exaggerated pain following pinprick to the skin)

- Pain when straight leg is raised, suggestive of irritation of lumbar nerve root

- Elicitation of myofascial trigger points to favour a diagnosis of myofascial pain over neuropathic pain

- Possible presence of Tinel's sign (distally radiating paresthesias upon percussion of damaged or regenerating nerve fibres)

Skin examination

- Alterations in temperature, colour, sweating and hair growth suggestive of complex regional pain syndrome ${ }^{34}$

- Residual dermatomal scars consistent with previous herpes zoster (shingles) infection

- Characteristic skin changes consistent with diabetes mellitus

Special tests

CT and MRI scans

- Facilitate specific diagnosis (e.g., herniated disc, nerve infiltration by tumour)

Electromyography and nerve conduction studies

- May provide objective evidence of nerve injury or dysfunction $^{35}$

- Nerve conduction studies evaluate large fibre function; therefore, small fibre neuropathy cannot be ruled out if results of nerve conduction studies are normal

Three-phase nuclear medicine bone scan

- May help diagnose complex regional pain syndrome ${ }^{36}$

Clinical biochemistry

- Conduct tests to help identify cause of neuropathy; for example, glucose tolerance testing, thyroid function, measurement of vitamin $B_{12}$ levels, CD4+ T-lymphocyte count 
efficacy and improvements in mood and sleep in several RCTs (NNT $=3.8) .{ }^{60,61}$ Pregabalin is a gabapentin analogue with a similar mechanism, higher calcium-channel affinity and better bioavailability. ${ }^{60,87}$ Pregabalin was superior to placebo in several RCTs in diabetic peripheral neuropathy and postherpetic neuralgia $(\mathrm{NNT}=4.2){ }^{61}$

RCTs of other anticonvulsants, including valproate, lamotrigine and topiramate, have had equivocal results. ${ }^{61}$

\section{Opioid analgesics}

The role of opioid analgesics in neuropathic pain has been controversial. However, a recent meta-analysis provides convincing evidence of benefit. ${ }^{88}$ Although I4 short-term RCTs ( $<24$ hours) showed contradictory results, 8 intermediateterm RCTs $(\leq 8$ weeks) demonstrated important efficacy. These RCTs demonstrated, on average, a $20 \%-30 \%$ pain reduction. For morphine and oxycodone, the NNT ranged from 2.5 to $2.6 .^{61}$ However, beneficial effects on mood, quality of life and disability are not consistent. ${ }^{89,90}$ There were no reports of addiction or abuse in these RCTs, although the risk is likely to be low given the common exclusion criterion of substance abuse history.$^{88}$ Currently, there is a dearth of evidence supporting the long-term efficacy of opioids in controlling neuropathic pain. However, the results of a recent retrospective review involving more than roo patients (most of whom had neuropathic pain) who had received chronic opioid therapy for I year or more suggest that many patients may continue to enjoy persistent pain relief with opioids. ${ }^{91}$

Tramadol is a weak opioid and a mixed serotoninnoradrenaline reuptake inhibitor. ${ }^{92}$ Three RCTs of tramadol for neuropathic pain have yielded an overall NNT of $3.9 .{ }^{61}$

Methadone is a synthetic opioid potentially useful for controlling neuropathic pain because of its NMDA-antagonist properties..$^{93}$ However, its long half-life (24-36 hours) necessitates extremely careful dose titration. ${ }^{94}$ Two small RCTs of methadone demonstrated benefit in managing neuropathic pain, ${ }^{95,96}$ and open-label experience suggests promise in a wide variety of neuropathic pain conditions. ${ }^{97}$

\section{NMDA antagonists}

Because of the critical role of NMDA activity in central sensitization, ${ }^{98} \mathrm{NMDA}$ antagonists hold promise in the management of neuropathic pain. Unfortunately, available agents have limited efficacy and produce intolerable side effects. Ketamine, an intravenous anesthetic with NMDA-antagonist activity, has been found to be effective in small RCTs; however,

Table 1: Clinical features and pathophysiology of common neuropathic pain syndromes

\begin{tabular}{|c|c|c|}
\hline Diagnosis (inciting cause) & Typical clinical features & Putative pathophysiology and clinical pathogenesis \\
\hline $\begin{array}{l}\text { Painful diabetic neuropathy } \\
\text { (hyperglycemia) }\end{array}$ & $\begin{array}{l}\text { Symmetrical sensory loss and } \\
\text { burning pain in lower legs }{ }^{37}\end{array}$ & $\begin{array}{l}\text { Hyperglycemia, hyperlipidemia, hypoinsulinemia, growth factor } \\
\text { deficiency } \longrightarrow \text { oxidative stress and autoimmunity } \longrightarrow \text { progressive } \\
\text { demyelination and axonal loss } \longrightarrow \text { sensory loss, paresthesia, } \\
\text { dysesthesias, pain and allodynia }{ }^{38-40}\end{array}$ \\
\hline $\begin{array}{l}\text { Lumbosacral radiculopathy } \\
\text { (herniated intervertebral } \\
\text { disc) }\end{array}$ & $\begin{array}{l}\text { Lancinating pain radiating into } \\
\text { the anterior thigh (L2/3) or } \\
\text { lower leg (L4-S1) with motor } \\
\text { weakness or sensory loss }\end{array}$ & $\begin{array}{l}\text { - Spinal nerve root compression }{ }^{41} \\
\text { - Inflammatory effects of extruded nucleus puloposus? }{ }^{42} \\
\text { - Sensory and motor abnormalities, radiating pain }\end{array}$ \\
\hline $\begin{array}{l}\text { Postherpetic neuralgia } \\
\text { (varicella zoster virus } \\
\text { infection) }\end{array}$ & $\begin{array}{l}\text { Unilateral pain, sensory loss or } \\
\text { allodynia in the dermatome } \\
\text { where herpes zoster had } \\
\text { previously erupted }^{43}\end{array}$ & $\begin{array}{l}\text { Dorsal horn atrophy, sensory ganglion (primary afferent neuron) } \\
\text { cell, axon and myelin loss and fibrosis }{ }^{44} \\
\text { - Sensitization of unmyelinated cutaneous nociceptors (“irritable } \\
\text { nociceptors") and/or } \\
\text { - Small fibre deafferentation and allodynia and/or } \\
\text { - Small and large fiber deafferentation } \\
\text { - Sensory loss, pain and allodynia }{ }^{5}\end{array}$ \\
\hline $\begin{array}{l}\text { Complex regional pain } \\
\text { syndrome } \\
\text { - Type } 1 \text { (previously "reflex } \\
\text { sympathetic dystrophy"- } \\
\text { no definable nerve lesion) } \\
\text { - Type } 2 \text { (previously } \\
\text { "causalgia" - nerve } \\
\text { injury) }\end{array}$ & $\begin{array}{l}\text { Regional (e.g., limb) pain } \\
\text { together with edema, } \\
\text { cutaneous blood flow and } \\
\text { sweating abnormalities }{ }^{46}\end{array}$ & $\begin{array}{l}\text { - "Coupling" of sympathetic neurons with injured sensory neurons at } \\
\text { peripheral neuroma sites or dorsal root ganglion sites of injured } \\
\text { afferent nerves } \longrightarrow \text { development of noradrenergic sensitivity } \\
\text { following nerve injury } \\
\text { - Pain, allodynia, hyperalgesia, edema, cutaneous blood flow and } \\
\text { sweating abnormalities }{ }^{47}\end{array}$ \\
\hline $\begin{array}{l}\text { Postsurgical neuropathic } \\
\text { pain (surgical procedure) }\end{array}$ & $\begin{array}{l}\text { Peri-incisional sensory loss, } \\
\text { pain and allodynia for more } \\
\text { than } 3 \text { months after surgery; } \\
\text { phantom pain following } \\
\text { amputation or mastectomy }\end{array}$ & $\begin{array}{l}\text { - Phantom pain in } 30 \%-81 \% \text { of amputations }{ }^{48} \\
\text { - Thoracotomy pain in } 11 \%-57 \% 48 \\
\text { - Postherniorrhaphy in } 37 \% \text { or less } \\
\text { - Postmastectomy pain in } 66 \%-83 \% \\
\text { - Poststernotomy in } 54 \% \text { or less }{ }^{49}\end{array}$ \\
\hline
\end{tabular}


psychomimetic side effects are dose limiting. ${ }^{99}$ Dextromethorphan, a common cough suppressant and NMDA antagonist, has produced uncertain results in controlling neuropathic pain, showing modest benefit in diabetic peripheral neuropathy, but not in postherpetic neuralgia. ${ }^{100}$

\section{Topical agents}

Locally acting analgesics are attractive because they may cause minimal systemic side effects. The lidocaine patch $5 \%$ has been shown to relieve localized pain in postherpetic neuralgia with no increase in side effects $(\mathrm{NNT}=4.4) \cdot{ }^{61} \mathrm{Al}-$ though the lidocaine patch $5 \%$ is not available in Canada, pharmacists can make up the gel or cream at a concentration of $5 \%-10 \% .{ }^{101}$ Capsaicin, an ingredient of hot peppers, has shown mixed results in RCTs ${ }^{61}$ and some patients with postherpetic neuralgia have reported pain exacerbation. One RCT evaluating topical doxepin, capsaicin and their combination demonstrated significant analgesia with all 3 of these interventions. ${ }^{102}$

\section{Miscellaneous drugs}

Mexiletine, an oral antiarrhythmic agent and sodium-channel blocker, was superior to placebo in only 2 of 7 RCTs. ${ }^{61}$ Clonidine, an $\alpha$-2-agonist sympathetic blocker, was shown to be effective in a subset of patients with diabetic peripheral neuropathy. ${ }^{103}$ Cannabinoids have been found to play a role in ex-

Injury-induced nerve changes in the periphery, dorsal root ganglia and spinal cord contribute to neuropathic pain syndromes
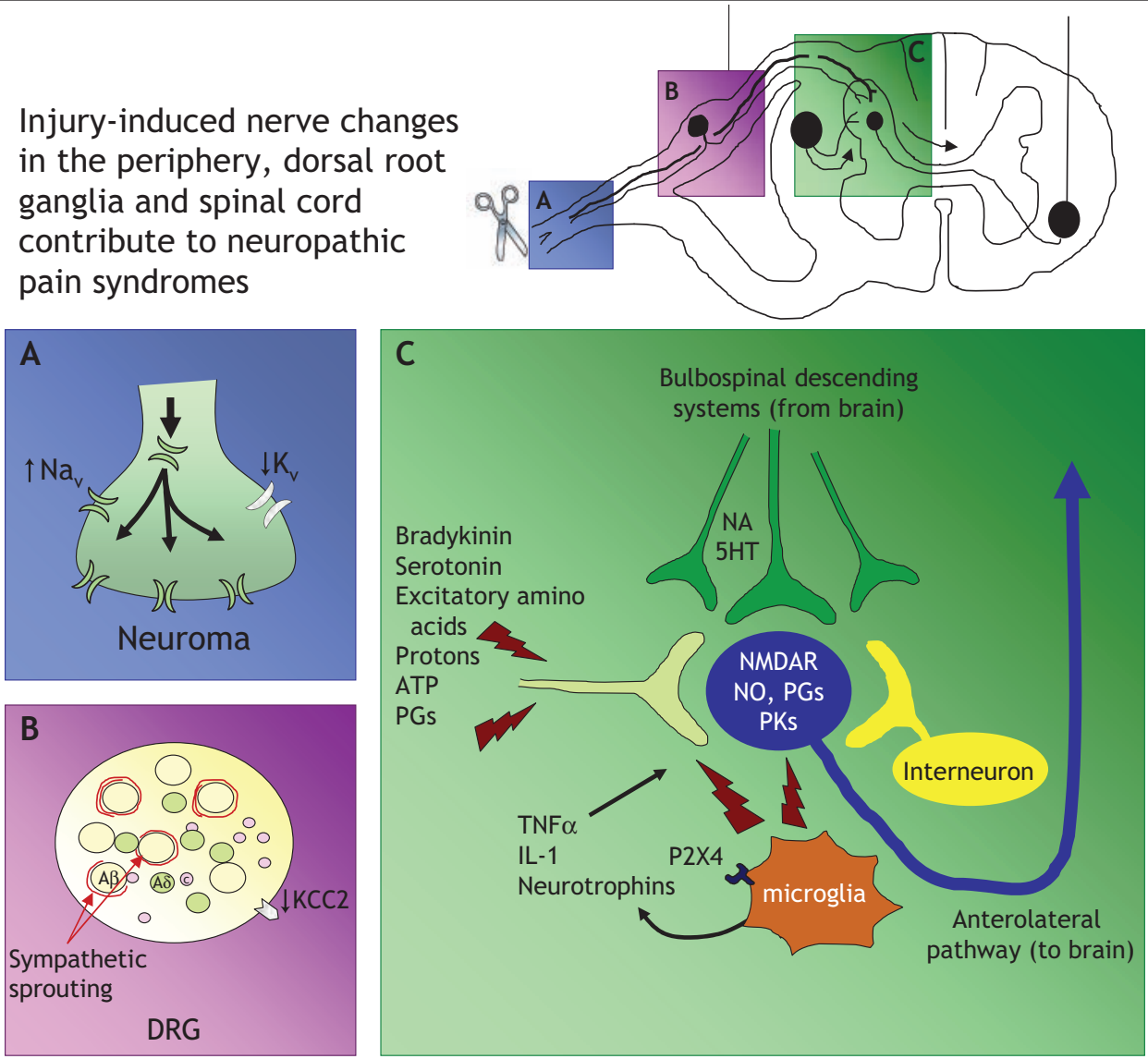

Fig 2: Neuropathic pain arises following nerve injury or dysfunction. A: After nerve damage, transcription and axonal trafficking of sodium channels to the site of injury is increased, with concomitant attenuation of potassium channels. The altered expression of ion channels results in neurons becoming hyperexcitable and generating ectopic activity, which is thought to lead to the genesis of spontaneous and paroxysmal pain. B: At the cell body of primary afferent neurons within the dorsal root ganglia (DRG), sympathetic neuronal sprouting occurs and may account for sympathetically maintained pain. C: Peripheral nerve injury causes a multitude of changes in gene transcription and activation of various kinases and proteins, including enhanced $\mathrm{N}$-methyl-D-aspartate (NMDA) receptor activity. However, nerve injury also elicits hypertrophy and activation of glial cells, including microglia within the grey matter of the spinal cord. Microglia express $\mathrm{P}_{2} \mathrm{X}_{4}$ purinergic receptors, allowing them to be activated by adenosine triphosphate (ATP). Following activation, microglia release various pronociceptive cytokines, such as interleukin-1 (IL-1), tumour necrosis factor alpha (TNF- $\alpha$ ) and neurotrophins, including brain-derived neurotrophic factor, which in turn exacerbates nociceptive transmission and contributes to the sensitization and maintenance of neuropathic pain. Note: $\mathrm{A} \beta=\mathrm{A}$ beta neuron, $\mathrm{A} \delta=\mathrm{A}$ delta neuron, $\mathrm{C}=\mathrm{C}$ nociceptor, $5 \mathrm{HT}=\mathrm{serotonin}, \mathrm{KCC} 2=\mathrm{chlo}-$ ride transporter, $\mathrm{NA}=$ noradrenaline, $\mathrm{Na}_{\mathrm{v}}=$ sodium channel, $\mathrm{NO}=$ nitric oxide, $\mathrm{K}_{\mathrm{v}}=$ potassium channel, $\mathrm{PGs}=$ prostaglandins, $\mathrm{PKs}=$ protein kinases, $\mathrm{P}_{2} \mathrm{X}_{4}=$ purinergic receptor. 
perimental pain modulation, ${ }^{105}$ and there is growing evidence of their efficacy in managing neuropathic pain. The cannabinoid dronabinol provided modest analgesic benefit in an RCT of central pain in multiple sclerosis. ${ }^{106}$ An oromucosal spray containing a mixture of tetrahydrocannabinol and cannabidiol provided modest benefit in another RCT of central pain in multiple sclerosis ${ }^{107}$ and in an RCT of neuropathic pain following brachial plexus avulsion. ${ }^{108}$

\section{Comparative trials}

Given the limitations of comparing treatments across trials using NNTs, several investigators have compared treatments within single trials. For example, 3 comparative RCTs suggest that analgesia with desipramine $e^{109,110}$ or nortriptyline $e^{111}$ is comparable to that of amitriptyline but with fewer side effects. Other studies suggest that opioids may be more efficacious than tricyclic antidepressants ${ }^{112}$ or gabapentin ${ }^{16}$ and that gabapentin is comparable to amitriptyline ${ }^{113}$ and venlafaxine analgesia is comparable to that of imipramine. ${ }^{114}$ These are, however, early impressions from small RCTs. Larger RCTs that incorporate head-to-head comparisons are needed.

\section{Combination pharmacotherapy}

Given the limited effectiveness of current treatments, combining different drugs may result in improved results at lower doses and with fewer side effects. Many patients with neuropathic pain currently receive drug combinations ${ }^{115}$ albeit in the absence of supportive evidence. In a recent RCT, analgesia with a morphine-gabapentin combination was superior to treatment with either drug alone. ${ }^{16}$ In a study involving II patients who did not respond to gabapentin, a gabapentinvenlafaxine combination was superior to gabapentin alone. ${ }^{116}$ In another RCT, the addition of the neuroleptic fluphenazine to amitriptyline therapy provided no benefit. ${ }^{117}$ Future trials are needed to evaluate optimal drug combinations and dose ratios as well as safety, compliance and cost-effectiveness. ${ }^{118}$

\section{Trigeminal neuralgia and other paroxysmal pain}

Trigeminal neuralgia and glossopharyngeal neuralgia (idiopathic or related to multiple sclerosis) are unique conditions. They are characterized by orofacial, paroxysmal, shock-like pains triggered by light, localized, tactile stimulation with minimal constant pain between paroxysms. These syndromes are also distinguished by their high responsiveness to carbamazepine. ${ }^{119}$ Baclofen is a muscle relaxant shown to be useful in trigeminal neuralgia in the setting of resistance to carbamazepine. ${ }^{104}$ High success rates have also been reported following invasive treatments such as microvascular decompression, trigeminal ganglion balloon compression and stereotactic (gamma knife) radiosurgery. ${ }^{120}$

\section{Interventional pain management}

Although rigorous supportive evidence is limited, more invasive treatments may be considered for patients with in- tractable neuropathic pain. ${ }^{121,122}$ Procedures include epidural or perineural injections of local anesthetics or corticosteroids, implantation of epidural and intrathecal drug delivery systems, neural ablative procedures (e.g., Gasserion ganglion glycerol injection or gamma knife surgery) and insertion of spinal cord stimulators, just to name a few. Consideration of highly invasive procedures such as insertion of intrathecal infusion pumps or spinal cord stimulators is generally reserved for patients with no surgically treatable pathology who have failed more conservative treatments and undergone psychological evaluation. ${ }^{123}$ Although this level of caution may also be applied to nerve block procedures, some conditions could warrant nerve blocks earlier in the clinical course. For example, sympathetic nerve blocks in early complex regional pain syndrome may be a crucial adjunct for the facilitation of physiotherapy and rehabilitation. ${ }^{124}$

\section{Approach to neuropathic pain management in primary care}

No single drug works for all neuropathic pain states, and given the diversity of pain mechanisms, patient responses and diseases, treatment must be individualized. Other than analgesia, factors to consider when individualizing therapy include tolerability, other benefits (e.g., improved sleep, mood and quality of life), low likelihood of serious adverse events and cost-effectiveness to the patient and the health care system. ${ }^{61}$ The evidence-based approach presented here may require revision as newer treatments and clinical evidence become available.

Pain management requires ongoing evaluation, patient education and reassurance. Diagnostic evaluation of treatable underlying conditions (e.g., spinal cord compression, herniated disc, neoplasm) should continue concurrently with pain management. Patients require education regarding the natural history of their condition and realistic treatment expectations (e.g., current treatments are not curative and analgesia is rarely complete). Even a $30 \%$ pain reduction is clinically important to patients. ${ }^{125}$ Pain severity, patient complexity (e.g., coexisting depression or substance abuse), failure of attempted treatments and availability of health care resources should be considered when planning referrals to pain clinics and related specialists. Patient compliance and adequacy of analgesic drug titrations (e.g., dose and duration of treatment) should be continually evaluated and documented.

Neuropathic pain is best managed with a multidisciplinary approach. Nevertheless, several different treatments can be initiated in the primary care setting (Fig. 3). Treatments with the lowest risk of adverse effects should be tried first. Evidence supporting conservative nonpharmacologic treatments (e.g., physiotherapy, exercise, transcutaneous electrical nerve stimulation) is limited; however, given their presumed safety, nonpharmacologic treatments should be considered whenever appropriate. ${ }^{61}$ Simple analgesics (e.g., acetaminophen, NSAIDs) are usually ineffective in pure neuropathic pain but may help with a coexisting nociceptive condition (e.g., sciatica with musculoskeletal low-back pain). Early referrals to a 
pain clinic for nerve blocks may be warranted in some cases to facilitate physiotherapy and pain rehabilitation.

Topical treatment with lidocaine, indicated for postherpetic neuralgia and focal neuropathy, could be tried first if it is available at a cost reasonable to the patient. For other neuropathic pain diagnoses or lidocaine treatment failures, we recommend initiating oral monotherapy with gabapentin or pregabalin, a tricyclic antidepressant, or a mixed serotonin-noradrenaline reuptake inhibitor. Of these treatments, gabapentin or pregabalin appear to be the best tolerated, with very few drug interactions. Tricyclic antidepressants appear to be more efficacious and much less expensive but have a higher likelihood of adverse effects and are relatively contraindicated for use in patients with serious cardiovascular disease (a screening electrocardiogram is recommended before prescribing tricyclic antidepressants), postural hypotension, urinary retention and angle-closure glaucoma. Among available tricyclic antidepressants, nortriptyline and desipramine are more highly recommended because of fewer side effects. Newer mixed serotonin-noradrenaline reuptake inhibitors (e.g., venlafaxine, duloxetine) may not be as efficacious as tricyclic antidepressants but appear to be better tolerated.

Little is known about whether the response to one drug predicts the response to another. However, if the first oral medication tried is ineffective or not tolerated, one might switch to alternate monotherapy. In the event that all of the first-line oral monotherapies tried are ineffective or poorly tolerated, we would then recommend initiating monotherapy with tramadol or an opioid analgesic. Long-term prescribing of opioid analgesics requires special prescribing and regulatory considerations. ${ }^{126-129}$ In Canada, where tramadol is available only as a fixed-dose combination with acetaminophen, the upper dose limit of tramadol will be dic-

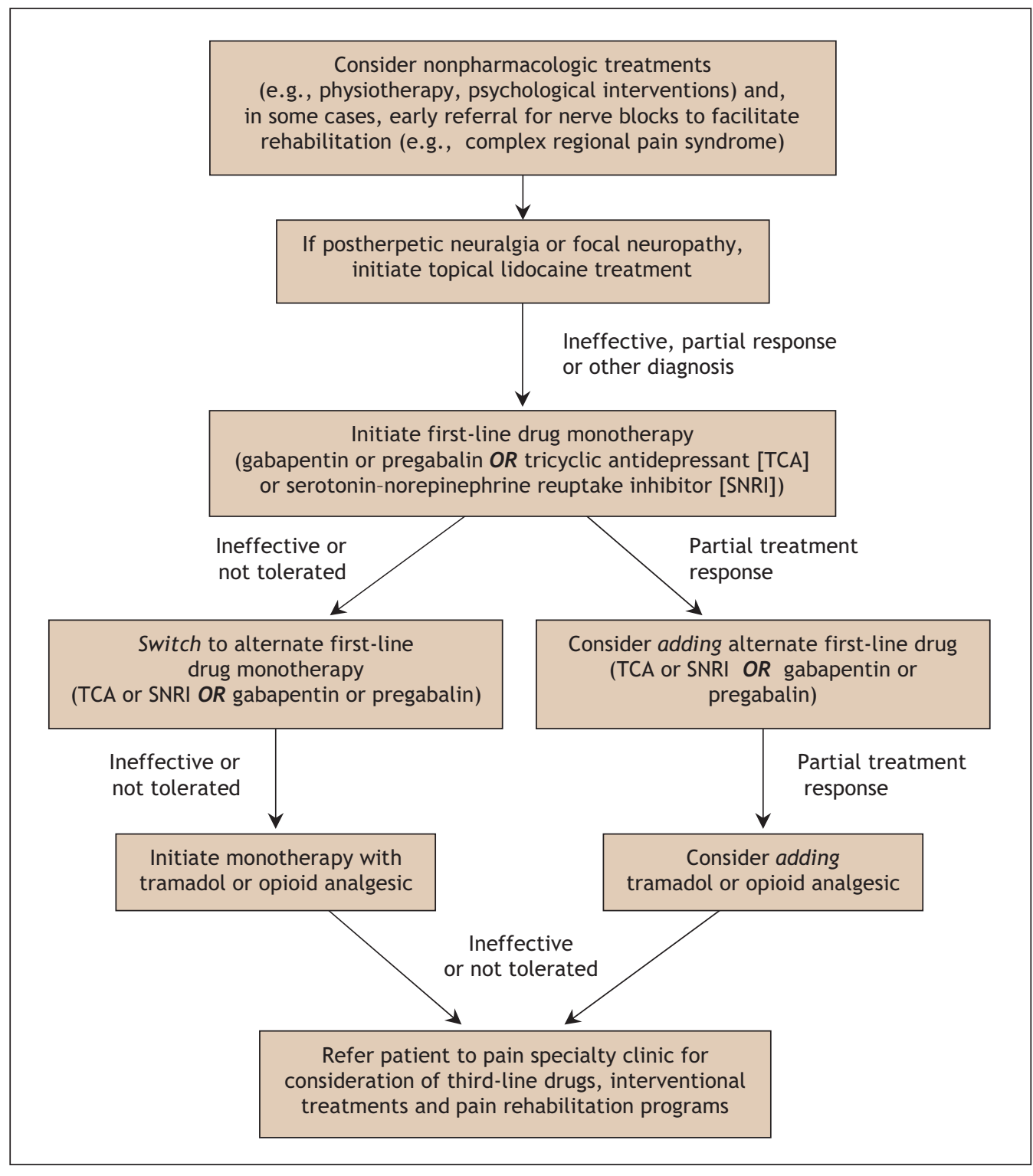

Fig. 3: Algorithm for the management of neuropathic pain in primary care. 
Table 2: Neuropathic pain medications*

\begin{tabular}{|c|c|c|c|c|c|}
\hline Drug & Drug interactions & Adverse effects & Dosage & $\begin{array}{c}\text { Usual } \\
\text { effective dose } \\
\text { (and maximum) }\end{array}$ & Comments \\
\hline \multicolumn{6}{|l|}{ SNRIs } \\
\hline Venlafaxine & $\begin{array}{l}\text { Metabolism by } \\
\text { CYP450 2D6 and } \\
\text { 3A4 }\end{array}$ & $\begin{array}{l}\text { Hypertension, ataxia, } \\
\text { sedation, insomnia, } \\
\text { nausea, hyperhidrosis, } \\
\text { dry mouth, constipation, } \\
\text { anxiety, anorexia }\end{array}$ & $\begin{array}{l}37.5 \mathrm{mg} \text { once } \\
\text { daily; increase } \\
\text { dose weekly by } \\
37.5 \mathrm{mg} / \mathrm{d}\end{array}$ & $\begin{array}{l}150-225 \mathrm{mg} / \mathrm{d} \\
\text { (maximum } \\
375 \mathrm{mg} / \mathrm{d} \text { ) }\end{array}$ & $\begin{array}{l}\text { Dose adjustment in } \\
\text { patients with renal } \\
\text { dysfunction; } \\
\text { contraindicated in } \\
\text { patients taking MAOIs }\end{array}$ \\
\hline \multicolumn{6}{|l|}{ Anticonvulsants } \\
\hline $\begin{array}{l}\text { Carbamazepine } \\
\text { (CBZ) }\end{array}$ & $\begin{array}{l}\text { Metabolism by } \\
\text { CYP450 3A4, 1A2 } \\
\text { and 2C8; inducer } \\
\text { of CYP450 1A2, 2C } \\
\text { and 3A }\end{array}$ & $\begin{array}{l}\text { Sedation, ataxia, rash, } \\
\text { diplopia, hyponatremia, } \\
\text { agranulocytosis, } \\
\text { nausea, diarrhea, } \\
\text { hepatotoxicity, aplastic } \\
\text { anemia, Stevens- } \\
\text { Johnson syndrome }\end{array}$ & $\begin{array}{l}100-200 \mathrm{mg} / \mathrm{d} \text {, } \\
\text { in divided doses } \\
\text { every } 6-8 \mathrm{~h} \text {; } \\
\text { increase dose } \\
\text { weekly by } \\
100-200 \mathrm{mg} / \mathrm{d}\end{array}$ & $\begin{array}{l}600-1200 \mathrm{mg} / \mathrm{d} \\
\text { (maximum } \\
1600 \mathrm{mg} / \mathrm{d}) \text {; for } \\
\text { trigeminal neuralgia, } \\
\text { controlled-release } \\
\text { CBZ every } 8-12 \mathrm{~h} \text {, } \\
\text { with short-acting } \\
\text { CBZ every } 4 \mathrm{~h} \text { for } \\
\text { rescue }\end{array}$ & $\begin{array}{l}\text { First-line therapy for } \\
\text { trigeminal neuralgia } \\
\text { only; contraindicated in } \\
\text { patients with porphyria } \\
\text { or atrioventricular block } \\
\text { and in those taking } \\
\text { MAOls; monitor CBC, liver } \\
\text { function test results and } \\
\text { blood levels }\end{array}$ \\
\hline Pregabalin & $\begin{array}{l}\text { None documented } \\
\text { to date }\end{array}$ & $\begin{array}{l}\text { Sedation, ataxia, } \\
\text { edema, diplopia, } \\
\text { weight gain, dry mouth }\end{array}$ & $\begin{array}{l}50-150 \mathrm{mg} / \mathrm{d} \text {, } \\
\text { in divided doses } \\
\text { every } 8-12 \mathrm{~h} \text {; } \\
\text { increase dose } \\
\text { weekly by } \\
50-150 \mathrm{mg} / \mathrm{d}\end{array}$ & $\begin{array}{l}300-600 \mathrm{mg} / \mathrm{d} \\
\text { (maximum } \\
600 \mathrm{mg} / \mathrm{d} \text { ) }\end{array}$ & $\begin{array}{l}\text { Dose adjustment in } \\
\text { patients with renal } \\
\text { dysfunction }\end{array}$ \\
\hline \multicolumn{6}{|l|}{ Opioids } \\
\hline Tramadol & $\begin{array}{l}\text { Metabolism by } \\
\text { CYP450 2D4; risk of } \\
\text { serotonin syndrome } \\
\text { with SSRI co- } \\
\text { administration }\end{array}$ & $\begin{array}{l}\text { Respiratory depression, } \\
\text { ataxia, sedation, } \\
\text { constipation, seizures, } \\
\text { nausea, orthostatic } \\
\text { hypotension }\end{array}$ & $\begin{array}{l}50 \mathrm{mg} / \mathrm{d} \text {, in } \\
\text { divided doses } \\
\text { every } 12 \mathrm{~h} \text {; } \\
\text { increase dose } \\
\text { weekly by } 50 \mathrm{mg} / \mathrm{d}\end{array}$ & $\begin{array}{l}200-400 \mathrm{mg} / \mathrm{d} \\
(\mathrm{maximum} \\
800 \mathrm{mg} / \mathrm{d})\end{array}$ & $\begin{array}{l}\text { Use with caution in } \\
\text { patients with epilepsy }\end{array}$ \\
\hline $\begin{array}{l}\text { Morphine } \\
\text { (or alternative } \\
\text { opioid with } \\
\text { appropriate dose } \\
\text { conversion) }\end{array}$ & $\begin{array}{l}\text { Potentiates other } \\
\text { sedatives }\end{array}$ & $\begin{array}{l}\text { Respiratory depression, } \\
\text { sedation, nausea, } \\
\text { constipation, cognitive } \\
\text { dysfunction }\end{array}$ & $\begin{array}{l}\text { 5-15 mg (short- } \\
\text { acting) every } 4 \mathrm{~h} \text { as } \\
\text { needed; after } 1-2 \\
\text { wk convert to long- } \\
\text { acting preparation } \\
\text { and continue dose } \\
\text { titration as needed }\end{array}$ & $\begin{array}{l}\text { Benefits of daily } \\
\text { morphine } \\
\text { equivalents }>180 \\
\text { mg/d have not } \\
\text { been established }\end{array}$ & $\begin{array}{l}\text { Screen patients for } \\
\text { alcohol/substance abuse } \\
\text { and consider "opioid } \\
\text { contract"; co-administer } \\
\text { pre-emptive stool } \\
\text { softeners and antiemetics }\end{array}$ \\
\hline
\end{tabular}

Note: CYP450 = cytochrome P450 enzyme, $\mathrm{MAOI}=$ monoamine oxidase inhibitor, SNRI = mixed serotonin-noradrenaline reuptake inhibitor, FDA = Food and Drug

Administration, $\mathrm{CBC}=$ complete blood count, $\mathrm{SSRI}=$ selective serotonin reuptake inhibitor .

*This is a nonexhaustive list that includes medications recommended in Fig. 3. 
tated by the risk of acetaminophen-related hepatotoxicity (i.e., < $4000 \mathrm{mg}$ acetaminophen).

Although supportive evidence is limited, polypharmacy may be helpful. Therefore, in the event of a partial response to any single drug, one could add an alternate drug. If none of the above tried treatments is effective or tolerated, referral to a pain clinic is warranted for consideration of thirdline drugs, interventional treatments and pain rehabilitation programs.

\section{Prescribing considerations}

Table 2 provides basic information on drugs recommended in Fig. 3. Given the potential for drug interactions, ${ }^{130}$ a thorough review of the patient's current medications is warranted before prescribing any drugs for neuropathic pain. Given the potential for overdose toxicity with opioids and tricyclic antidepressants, suicide risk should be evaluated before prescribing. Some patients need reassurance that analgesia with antidepressants and anticonvulsants does not necessarily imply a diagnosis of depression or epilepsy. Because the central nervous system is depressed by most tricyclic antidepressants, anticonvulsants and opioids, gradual drug dose titration over weeks, toward a maximal tolerated dose, allows for accommodation to adverse effects while reaching an effective dose. Because of this need for gradual dose titration, the physician and patient need to recognize that onset of pain relief will be gradual. If possible, nursing resources should be devoted to weekly patient contact to guide dose titration. Since tricyclic antidepressants are rapidly metabolized in some patients, plasma tricyclic antidepressant levels should be measured if no analgesic or adverse effects are observed at maximal doses so as to safely guide further dose increases. ${ }^{131}$ In elderly people, drug treatment should be started at the lowest possible dose and be increased very slowly (i.e., longer titration period) to minimize the risk of falling and related trauma.

\section{Conclusion}

Neuropathic pain is a devastating chronic condition that generally can be diagnosed by history and findings on physical examination. For some neuropathic pain syndromes, available treatments are tolerable and afford meaningful relief to a considerable proportion of patients. Nevertheless, many patients report intractable and severe pain, and better treatment strategies are desperately needed. ${ }^{132}$ The field of neuropathic pain research and treatment is in the early stages of development, with many goals yet to be achieved. In particular, future laboratory, clinical and epidemiologic ${ }^{3,9}$ research into pathogenesis, ${ }^{64,136}$ treatment $^{2,18,118,137,138}$ and prevention $^{133-135}$ of neuropathic pain is expected as well as improved dissemination of new information to health professionals and the public. Over the years to come, many upcoming advances are expected in the basic and clinical science of neuropathic pain as well as in the implementation of improved therapies for patients who continue to experience these devastating conditions.
This article has been peer reviewed.

From the Departments of Anesthesiology and of Pharmacology \& Toxicology (Gilron, Cahill), Queen's University and Kingston General Hospital, Kingston, Ont.; the Department of Medicine (Watson), University of Toronto, Toronto, Ont.; Pain and Symptom Management (Moulin), London Regional Cancer Program and Departments of Clinical Neurological Sciences and Oncology, University of Western Ontario, London, Ont.

Competing interests: None declared for Catherine Cahill. Ian Gilron has received research support from Pfizer, Aventis Pharma, Novopharm, PharmaScience and Apotex, and he has received honoraria for consultations and speaker fees for educational presentations from Pfizer, Merck Frosst, Johnson \& Johnson, Ortho-McNeill and Janssen-Ortho. Peter Watson has received speaker fees for educational presentations from Purdue Pharma and Merck Frosst. Dwight Moulin has received research grants from Pfizer, Purdue Pharma and Janssen-Ortho; honoraria for consultations and speaker fees for educational presentations from Pfizer, Purdue Pharma, Merck Frosst, Janssen-Ortho and Bayer; and an educational grant from Pfizer for the Neuropathic Pain Significant Interest Group of the Canadian Pain Society.

Contributors: All of the authors contributed substantially to the conception, analysis and interpretation of the information presented, as well as drafting and critically revising the article. All of the authors approved the final version to be published.

Acknowledgements: We thank Drs. Mitchell Max and Neil Hobbs for thoughtful comments made on previous versions of this manuscript.

This work was supported in part by grant 69422 from the Canadian Institutes of Health Research and grant 383-86I from Queen's University.

\section{REFERENCES}

I. Classification of chronic pain: descriptions of chronic pain syndromes and definitions of pain terms. In: Merskey H, Bogduk N, editors. Task force on taxonomy of the IASP. 2nd edition. Seattle: IASP Press; 1994, p. 209-I4.

2. Dworkin RH, Backonja M, Rowbotham MC, et al. Advances in neuropathic pain. Arch Neurol 2003;60:1524-34.

3. Boulton AJ, Armstrong WD, Scarpello JH, et al. The natural history of painful diabetic neuropathy — a 4-year study. Postgrad Med J I983;59:556-9.

4. Max MB, Schafer SC, Culnane M, et al. Association of pain relief with drug side effects in postherpetic neuralgia: a single-dose study of clonidine, codeine, ibuprofen, and placebo. Clin Pharmacol Ther I988;43:363-7I.

5. Fields HL, Rowbotham M, Baron R. Postherpetic neuralgia: irritable nociceptors and deafferentation. Neurobiol Dis 1998;5:209-27.

6. Jensen TS, Gottrup H, Sindrup SH, et al. The clinical picture of neuropathic pain. Eur J Pharmacol 200I;429:I-II.

7. Foley KM. Opioids and chronic neuropathic pain. NEngl J Med 2003;348:1279-8I.

8. Heliovaara M, Impivaara O, Sievers K, et al. Lumbar disc syndrome in Finland. $J$ Epidemiol Community Health $\mathrm{I} 987 ; 4 \mathrm{I}: 25 \mathrm{I}-8$.

9. Schmader KE. Epidemiology and impact on quality of life of postherpetic neuralgia and painful diabetic neuropathy. Clin J Pain 2002;18:350-4.

Io. Davis MP, Walsh D. Epidemiology of cancer pain and factors influencing poor pain control. Am J Hosp Palliat Care 2004;21:137-42.

II. Verma S, Estanislao L, Simpson D. HIV-associated neuropathic pain: epidemiology, pathophysiology and management. CNS Drugs 2005;I9:325-34.

I2. Werhagen L, Budh CN, Hultling C, et al. Neuropathic pain after traumatic spinal cord injury-relations to gender, spinal level, completeness, and age at the time of injury. Spinal Cord 2004;42:665-73.

13. Sandroni P, Benrud-Larson LM, McClelland RL, et al. Complex regional pain syndrome type I: incidence and prevalence in Olmsted county, a population-based study. Pain 2003;103:199-207.

I4. Melzack R. The short-form McGill Pain Questionnaire. Pain I987;30:19I-7.

I5. Masson EA, Hunt L, Gem JM, et al. A novel approach to the diagnosis and assessment of symptomatic diabetic neuropathy. Pain $1989 ; 38: 25-8$.

I6. Gilron I, Bailey JM, Tu D, et al. Morphine, gabapentin, or their combination for neuropathic pain. $N$ Engl JMed 2005;352:1324-34.

17. Atlas SJ, Deyo RA, Patrick DL, et al. The Quebec Task Force classification for Spinal Disorders and the severity, treatment, and outcomes of sciatica and lumbar spinal stenosis. Spine I996;21:2885-92.

I8. Coplan PM, Schmader K, Nikas A, et al. Development of a measure of the burden of pain due to herpes zoster and postherpetic neuralgia for prevention trials: adaptation of the brief pain inventory. J Pain 2004;5:344-56.

I9. Berger A, Dukes EM, Oster G. Clinical characteristics and economic costs of patients with painful neuropathic disorders. J Pain 2004;5:143-9.

20. Turk DC. Clinical effectiveness and cost-effectiveness of treatments for patients with chronic pain. Clin J Pain 2002;18:355-65.

2I. Galer B, Jensen M. Development and preliminary validation of a pain measure specific to neuropathic pain. The neuropathic pain scale. Neurology 1997;48:332-8. 
22. Bennett M. The LANSS Pain Scale: The Leeds assessment of neuropathic symptoms and signs. Pain 2001;92:147-57.

23. Krause SJ, Backonja MM. Development of a neuropathic pain questionnaire. Clin J Pain 2003;I9:306-I4.

24. Backonja MM, Krause SJ. Neuropathic pain questionnaire - short form. Clin J Pain 2003;19:315-6.

25. Bouhassira D, Attal N, Fermanian J, et al. Development and validation of the neuropathic pain symptom inventory. Pain 2004;108:248-57.

26. Bouhassira D, Attal N, Alchaar H, et al. Comparison of pain syndromes associated with nervous or somatic lesions and development of a new neuropathic pain diagnostic questionnaire (DN4). Pain 2005;II4:29-36.

27. Backonja MM, Galer BS. Pain assessment and evaluation of patients who have neuropathic pain. Neurol Clin 1998;16:775-90.

28. Odrcich M, Bailey JM, Cahill CM, et al. Chronobiological characteristics of painful diabetic neuropathy and postherpetic neuralgia: Diurnal pain variation and effects of analgesic therapy. Pain 2006;120:207-I2.

29. Smith MT, Haythornthwaite JA. How do sleep disturbance and chronic pain interrelate? Insights from the longitudinal and cognitive-behavioral clinical trials literature. Sleep Med Rev 2004;8:II9-32.

30. Haythornthwaite JA, Benrud-Larsen LM. Psychological aspects of neuropathic pain. Clin J Pain 2000;16:SIoI-5.

3I. Smith MT, Edwards RR, Robinson RC, et al. Suicidal ideation, plans, and attempts in chronic pain patients: factors associated with increased risk. Pain 2004;III:20I-8.

32. Richeimer SH, Bajwa ZH, Kahraman SS, et al. Utilization patterns of tricyclic antidepressants in a multidisciplinary pain clinic: a survey. Clin J Pain 1997;13:324-9.

33. Michna E, Ross EL, Hynes WL, et al. Predicting aberrant drug behavior in patients treated for chronic pain: importance of abuse history. J Pain Symptom Manage 2004;28:250-8.

34. Wilson P, Stanton-Hicks M, Harden RN, editors. CRPS: current diagnosis and therapy. [Volume 32 in Progress in pain research and management series]. Seattle: IASP Press; 2005.

35. Mendell JR, Sahenk Z. Clinical practice. Painful sensory neuropathy. N Engl J Med 2003;348:1243-55.

36. Kozin F, Soin JS, Ryan LM, et al. Bone scintigraphy in the reflex sympathetic dystrophy syndrome. Radiology $198 \mathrm{I} ; \mathrm{I} 38: 437-43$.

37. Sinnreich M, Taylor BV, Dyck PJ. Diabetic neuropathies. Classification, clinical features, and pathophysiological basis. Neurologist 2005;II:63-79.

38. Vinik AI. Diabetic neuropathy: pathogenesis and therapy. Am J Med I999;107(2B):17S-26S.

39. Dyck PJ, Lambert EH, O'Brien PC. Pain in peripheral neuropathy related to rate and kind of fiber degeneration. Neurology $1976 ; 26: 466-71$.

40. Attal N, Bouhassira D. Mechanisms of pain in peripheral neuropathy. Acta Neurol Scand Suppl 1999;173:12-24.

4I. Garfin SR, Rydevik B, Lind B, et al. Spinal nerve root compression. Spine I995;20:I8I0-20.

42. Mulleman D, Mammou S, Griffoul I, et al. Pathophysiology of disk-related sciatica. I. Evidence supporting a chemical component. Joint Bone Spine 2006;73:15I-8.

43. Oaklander AL. The pathology of shingles: Head and Campbell's Igoo monograph. Arch Neurol I999;56:1292-4.

44. Watson CP, Deck JH, Morshead C, et al. Post-herpetic neuralgia: further postmortem studies of cases with and without pain. Pain 1991;44:105-I7.

45. Brew BJ. The peripheral nerve complications of human immunodeficiency virus (HIV) infection. Muscle Nerve 2003;28:542-52.

46. Stanton-Hicks M, Janig W, Hassenbusch S, et al. Reflex sympathetic dystrophy: changing concepts and taxonomy. Pain I995;63:127-33.

47. Baron R, Levine JD, Fields HL. Causalgia and reflex sympathetic dystrophy: does the sympathetic nervous system contribute to the generation of pain? Muscle Nerve I999;22:678-95

48. Perkins FM, Kehlet $\mathrm{H}$. Chronic pain as an outcome of surgery. A review of predictive factors. Anesthesiology 2000;93:1123-33

49. Alston RP, Pechon P. Dysaesthesia associated with sternotomy for heart surgery. BrJ Anaesth 2005;95:153-8.

50. Walker K, Fox AJ, Urban LA. Animal models for pain research. Mol Med Today I999;5:319-2I.

5I. Hansson PT, Dickenson AH. Pharmacological treatment of peripheral neuropathic pain conditions based on shared commonalities despite multiple etiologies. Pain 2005;II3:25I-4

52. Devor M, Lomazov P, Matzner O. Sodium channel accumulation in injured axons as a substrate for neuropathic pain. In: Boivie J, Hansson P, Lindblom U, editors. Touch, temperature and pain in health and disease: mechanisms and assessments. [Volume 3 in Progress in pain research and management series.] Seattle: IASP Press; I994. p. 207-30.

53. Wall PD, Gutnick M. Properties of afferent nerve impulses originating from a neuroma. Nature I974;248:740-3.

54. Devor M. Neuropathic pain: what do we do with all these theories? Acta Anaesthesiol Scand 200I;45:II2I-7.

55. Zhang J-M, Li H, Brull SJ. Perfusion of the mechanically compresed lumbar ganglion with lidocaine reduces mechanical hyperalgesia and allodynia in the rat. $J$ Neurophysiol 2000;84:798-805.

56. Waxman SG, Cummins TR, Dib-Hajj S, et al. Sodium channels, excitability of primary sensory neurons, and the molecular basis of pain. Muscle Nerve 1999;22:1177-87.

57. Matthews EA, Dickenson AH. Effects of spinally delivered N- and P-type voltagedependent calcium channel antagonists on dorsal horn neuronal responses in a rat model of neuropathy. Pain 2001;92:235-46

58. White DM, Zimmermann M. The bradykinin-induced release of substance P from nerve fibre endings in the rat saphenous nerve neuroma is not related to electrophysiological excitation. Neurosci Lett I988;92:108-I3.

59. Luo ZD, Chaplan SR, Higuera ES, et al. Upregulation of dorsal root ganglion (alpha)2(delta) calcium channel subunit and its correlation with allodynia in spinal nerve-injured rats. J Neurosci 200I;21:1868-75.

6o. Gilron I, Flatters SJL. Gabapentin and pregabalin for the treatment of neuropathic pain: A review of laboratory and clinical evidence. Pain Res Manage 2006;II(Suppl A): $16 \mathrm{~A}-29 \mathrm{~A}$

6I. Finnerup NB, Otto M, McQuay HJ, et al. Algorithm for neuropathic pain treatment: An evidence based proposal. Pain 2005;118:289-305.

62. Dickenson A, Matthews E, Suzuki R. Central nervous system mechanisms of pain in peripheral neuropathy. In: Hansson P, Fields H, Hill R, Marchettini P, editors. Neuropathic pain: pathophysiology and treatment. [Volume 2I in Progress in pain research and management series.] Seattle: IASP Press; 200I. p. 85-106.

63. Woolf CJ, Salter MW. Neuronal plasticity — increasing the gain in pain. Science 2000;288:1765-8.

64. Woolf CJ, Mannion RJ. Neuropathic pain: aetiology, symptoms, mechanisms, and management. Lancet 1999;353:1959-64.

65. Yaksh TL, Hua XY, Kalcheva I, et al. The spinal biology in humans and animals of pain states generated by persistent small afferent input. Proc Natl Acad Sci U S A I999;96:7680-6.

66. Porreca F, Ossipov M, Gebhart G. Chronic pain and medullary descending facilitation. Trends Neurosci 2002;25:319-25.

67 . Reynolds DV. Surgery in the rat during electrical analgesia induced by focal brain stimulation. Science i969;164:444-5.

68. Mayer DJ. Analgesia produced by electrical stimulation of the brain. Prog Neuropsychopharmacol Biol Psychiatry 1984;8:557-64.

69. Fields HL, Basbaum AI. Central nervous system mechanisms of pain modulation. In: Wall PD, Melzack R, editors. Textbook of pain. Edinburgh: Churchill Livingstone; 1999. p. 309-29.

70. Fields HL. Is there a facilitating component to central pain modulation? Am Pain Soc JI992;I:7I-8.

7I. Chung K, Lee BH, Yoon YW, et al. Sympathetic sprouting in the dorsal root ganglia of the injured peripheral nerve in a rat neuropathic pain model. J Comp Neurol I996;376:24I-52.

72. Raja SN, Treede RD, Davis KD, et al. Systemic alpha-adrenergic blockade with phentolamine: a diagnostic test for sympathetically maintained pain. Anesthesiology I99I;74:69I-8.

73. Koltzenburg M, McMahon SB. The enigmatic role of the sympathetic nervous system in chronic pain. Trends Pharmacol Sci I991;12:399-402.

74. Chung K, Yoon YW, Chung JM. Sprouting sympathetic fibers form synaptic varicosities in the dorsal root ganglion of the rat with neuropathic injury. Brain Res I997;75I:275-80.

75. Grelik C, Bennett GJ, Ribeiro-da-Silva A. Autonomic fibre sprouting and changes in nociceptive sensory innervation in the rat lower lip skin following chronic constriction injury. Eur J Neurosci 2005;21:2475-87.

76. Sherry DD, Wallace CA, Kelley C, et al. Short- and long-term outcomes of children with complex regional pain syndrome type I treated with exercise therapy. Clin Pain 1999;15:218-23.

77. Kumar D, Marshall HJ. Diabetic peripheral neuropathy: amelioration of pain with transcutaneous electrostimulation. Diabetes Care 1997;20:1702-5.

78. Ghoname EA, White PF, Ahmed HE, et al. Percutaneous electrical nerve stimulation: an alternative to TENS in the management of sciatica. Pain 1999;83:193-9.

79. Moseley GL. Graded motor imagery is effective for long-standing complex regional pain syndrome: a randomised controlled trial. Pain 2004;108:192-8.

8o. Evans S, Fishman B, Spielman L, et al. Randomized trial of cognitive behavior therapy versus supportive psychotherapy for HIV-related peripheral neuropathic pain. Psychosomatics 2003;44:44-50.

8I. McQuay HJ, Tramer M, Nye BA, et al. A systematic review of antidepressants in neuropathic pain. Pain 1996;68:217-27.

82. Stahl SM. Basic psychopharmacology of antidepressants, part I: Antidepressants have seven distinct mechanisms of action. JClin Psychiatry I998;59(Suppl 4):5-I4.

83. Sindrup SH, Jensen TS. Efficacy of pharmacological treatments of neuropathic pain: an update and effect related to mechanism of drug action. Pain 1999;83:389-400.

84. Goldstein DJ, Lu Y, Detke MJ, et al. Duloxetine vs. placebo in patients with painful diabetic neuropathy. Pain 2005; II6:109-18.

85. Dogra S, Beydoun S, Mazzola J, et al. Oxcarbazepine in painful diabetic neuropathy: a randomized, placebo-controlled study. Eur J Pain 2005;9:543-54.

86. Bryans JS, Wustrow DJ. 3-substituted GABA analogs with central nervous system activity: a review. Med Res Rev I999;I9:I49-77.

87. Shneker BF, McAuley JW. Pregabalin: a new neuromodulator with broad therapeutic indications. Ann Pharmacother 2005;39:2029-37.

88. Eisenberg E, McNicol ED, Carr DB. Efficacy and safety of opioid agonists in the treatment of neuropathic pain of nonmalignant origin. JAMA 2005;293:3043-52.

89. Watson CP, Moulin D, Watt-Watson J, et al. Controlled-release oxycodone relieves neuropathic pain: a randomized controlled trial in painful diabetic neuropathy. Pain 2003;105:7I-8.

90. Gimbel JS, Richards P, Portenoy RK. Controlled-release oxycodone for pain in diabetic neuropathy: a randomized controlled trial. Neurology 2003;60:927-34.

9r. Watson CP, Watt-Watson JH, Chipman ML. Chronic noncancer pain and the long term utility of opioids. Pain Res Manag 2004;9:19-24.

92. Harati Y, Gooch C, Swenson M, et al. Double blind randomized trial of tramado 
for the treatment of the pain of diabetic neuropathy. Neurology I998;50:1842-6.

93. Ebert B, Thorkildsen C, Andersen S, et al. Opioid analgesics as noncompetitive Nmethyl-D-aspartate (NMDA) antagonists. Biochem Pharmacol I998;56:553-9.

94. Lynch ME. A review of the use of methadone for the treatment of chronic noncancer pain. Pain Res Manag 2005;10:133-44

95. Gagnon B, Almahrezi A, Schreier G. Methadone in the treatment of neuropathic pain. Pain Res Manage 2003;8:149-54

96. Morley JS, Bridson J, Nash TP, et al. Low dose methadone has an analgesic effect in neuropathic pain: a double-blind randomized controlled crossover trial. Palliat Med 2003;17:576-87.

97. Moulin DE, Palma D, Watling C, et al. Methadone in the management of intractable neuropathic noncancer pain. Can J Neurol Sci 2005;32:340-3.

98. Woolf CJ, Thompson SW. The induction and maintenance of central sensitization is dependent on N-methyl-D-aspartic acid receptor activation; implications for the treatment of post-injury pain hypersensitivity states. Pain I991;44:293-9.

99. Hocking G, Cousins MJ. Ketamine in chronic pain management: an evidencebased review. Anesth Analg 2003;97:1730-9.

Ioo. Sang CN, Booher S, Gilron I, et al. Dextromethorphan and memantine in painfu diabetic neuropathy and postherpetic neuralgia: efficacy and dose-response trials Anesthesiology 2002;96:1053-6r

IOI. Kang L, Jun HW. Formulation and efficacy studies of new topical anesthetic creams. Drug Dev Ind Pharm 2003;29:505-I2.

I02. McCleane G. Topical application of doxepin hydrochloride, capsaicin and a combination of both produces analgesia in chronic human neuropathic pain: a randomized, double-blind, placebo-controlled study. BrJ Clin Pharmacol 2000;49:574-9.

I03. Byas-Smith MG, Max MB, Muir J, et al. Transdermal clonidine compared to placebo in painful diabetic neuropathy using a two-stage "enriched enrolment" design. Pain 1995;60:267-74.

I04. Fromm GH, Terance CF, Chatta AS. Baclofen in the treatment of trigeminal neuralgia. Ann Neurol I984;15:240-7.

105. Cravatt BF, Lichtman AH. The endogenous cannabinoid system and its role in nociceptive behavior. JNeurobiol 2004;61:149-60.

Io6. Svendsen KB, Jensen TS, Bach FW. The cannabinoid dronabinol reduces centra pain in multiple sclerosis. A randomized double-blind placebo-controlled crossover trial. $B M J$ 2004;329:253-6r.

I07. Rog DJ, Nurmikko TJ, Friede T, et al. Randomized, controlled trial of cannabisbased medicine in central pain in multiple sclerosis. Neurology 2005;65:812-9.

Io8. Berman JS, Symonds C, Birch R. Efficacy of two cannabis based medicinal extracts for relief of central neuropathic pain from brachial plexus avulsion: results of a randomized controlled trial. Pain 2004;1I2:299-306.

I09. Max MB, Lynch SA, Muir J, et al. Effects of desipramine, amitriptyline, and fluoxetine on pain in diabetic neuropathy. N Engl J Med I992;326:1250-6.

IIo. Rowbotham MC, Reisner LA, Davies PS, et al. Treatment response in antidepressant-naive postherpetic neuralgia patients: double-blind, randomized trial. J Pain 2005;6:74I-6

III. Watson CP, Vernich L, Chipman M, et al. Nortriptyline versus amitriptyline in postherpetic neuralgia: a randomized trial. Neurology i998;51:1166-71

II2. Raja SN, Haythornthwaite JA, Pappagallo M, et al. Opioids versus antidepressants in postherpetic neuralgia: a randomized, placebo-controlled trial. Neurology 2002;59:1015-2I.

II3. Morello CM, Leckband SG, Stoner CP, et al. Randomized double-blind study comparing the efficacy of gabapentin with amitriptyline on diabetic peripheral neuropathy pain. Arch Intern Med I999;I59:I93I-7.

II4. Sindrup SH, Bach FW, Madsen C, et al. Venlafaxine versus imipramine in painful polyneuropathy: a randomized, controlled trial. Neurology 2003;60:1284-9.

II5. Gilron I, Bailey JM. Trends in opioid use for chronic neuropathic pain: a survey of patients pursuing enrollment in clinical trials. Can J Anaesth 2003;50:42-7.

II6. Simpson DA. Gabapentin and venlafaxine for the treatment of painful diabetic neuropathy. JClin Neuromusc Disease 2001;3:53-62.

II7. Graff-Radford SB, Shaw LR, Naliboff BN. Amitriptyline and fluphenazine in the treatment of postherpetic neuralgia. Clin J Pain 2000;16:188-92.

II8. Gilron I, Max MB. Combination pharmacotherapy for neuropathic pain: current evidence and future directions. Expert Rev Neurother 2005;5:823-30.

IIg. Sindrup SH, Jensen TS. Pharmacotherapy of trigeminal neuralgia. Clin J Pain 2002;18:22-7.

I20. Lopez BC, Hamlyn PJ, Zakrzewska JM. Systematic review of ablative neurosurgical techniques for the treatment of trigeminal neuralgia. Neurosurgery 2004;54:973-82.

I2I. Krames E. Implantable devices for pain control: spinal cord stimulation and in trathecal therapies. Best Pract Res Clin Anaesthesiol 2002;16:619-49.

I22. Peng PW, Castano ED. Survey of chronic pain practice by anesthesiologists in Canada. Can J Anaesth 2005;52:383-9.

I23. Gybels J, Erdine S, Maeyaert J, et al. Neuromodulation of pain. A consensus statement prepared in Brussels I6-I8 January I 998 by the following task force of the European Federation of IASP Chapters (EFIC). Eur J Pain I998;2:203-9.

124. Stanton-Hicks M, Baron R, Boas R, et al. Complex Regional Pain Syndromes: guidelines for therapy. Clin J Pain I998;I4:155-66

I25. Farrar JT, Young JP Jr, LaMoreaux L, et al. Clinical importance of changes in chronic pain intensity measured on an II-point numerical pain rating scale. Pain 200I;94:I49-58

I26. Portenoy RK. Opioid therapy for chronic nonmalignant pain: a review of the critical issues. J Pain Symptom Manage 1996;11:203-17

27. Jovey JD, Ennis J, Gardner-Nix J, et al. Use of opioid analgesics for the treatment of chronic noncancer pain - a consensus statement and guidelines from the Canadian Pain Society. Pain Res Manage 1998;3:197-222.

I28. Ballantyne JC, Mao J. Opioid therapy for chronic pain. $N$ Engl J Med 2003;349:1943-53

I29. American Pain Society. The use of opioids for the treatment of chronic pain: a consensus statement from the American Academy of Pain Medicine and the American Pain Society. Glenview, IL: The Society; I997.

I30. Virani A, Mailis A, Shapiro LE, et al. Drug interactions in human neuropathic pain pharmacotherapy. Pain 1997;73:3-13

I3I. Max MB, Gilron I. Antidepressants, muscle relaxants, and NMDA receptor antagonists. In: Loeser JD, Turk D, Chapman CR, Butler S, editors. Bonica's management of pain. 3 rd edition. Baltimore: Williams \& Wilkins; 200I. p. 1710-26.

I32. Gallagher RM. Neuropathic pain: the global challenge. Pain Med 2004;5(Suppl I):SI-2.

I33. Oxman MN, Levin MJ, Johnson GR, et al. A vaccine to prevent herpes zoster and postherpetic neuralgia in older adults. N Engl J Med 2005;352:227I-84.

I34. Fassoulaki A, Triga A, Melemeni A, et al. Multimodal analgesia with gabapentin and local anesthetics prevents acute and chronic pain after breast surgery for cancer. Anesth Analg 2005; I0I:I427-32.

I35. The effect of intensive diabetes therapy on the development and progression of neuropathy. The Diabetes Control and Complications Trial Research Group. Ann Intern Med I995; I22:56I-8

I36. Belfer I, Wu T, Kingman A, et al. Candidate gene studies of human pain mechanisms: methods for optimizing choice of polymorphisms and sample size. Anesthesiology 2004; 100:1562-72.

I37. Thompson D. Toward a pharmacoeconomic model of neuropathic pain. Clin Pain 2002;18:366-72.

138. Woolf CJ, Max MB. Mechanism-based pain diagnosis. Anesthesiology 200I;95:24I-9

Correspondence to: Dr. Ian Gilron, Director of Clinical Pain Research, Department of Anesthesiology, Kingston General Hospital, Victory 2 Pavilion, 76 Stuart St., Kingston $\mathrm{ON} \mathrm{K}_{7} \mathrm{~L}_{2} \mathrm{~V}_{7}$; fax613 548-I375; gilroni@post.queensu.ca

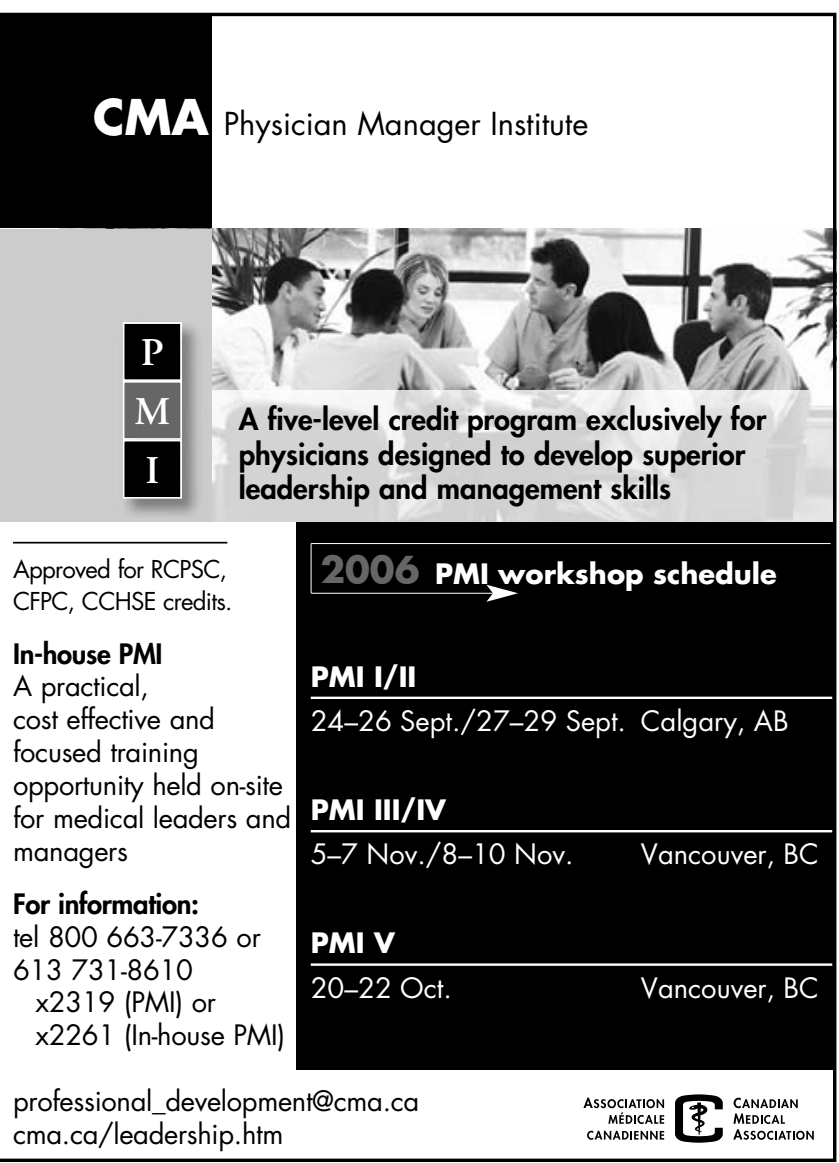

